\title{
Concepções acerca da formação docente em química: desafios e possibilidades
}

Conceptions about teacher formation in chemistry challenges and possibilities

Concepciones acerca de la formación docente en química: desafíos y posibilidades

Lairton Tres - Universidade de Passo Fundo | Instituto de Ciências Exatas e Geociências | Passo Fundo | RS | Brasil. E-mail: lairton@upf.br

José Claudio Del Pino - Universidade Federal do Rio Grande do Sul | Departamento de Bioquímica | Porto Alegre | RS | Brasil. E-mail: delpinojc@yahoo.com.br

Resumo: A formação docente traz à tona inúmeros desafios para serem enfrentados num curso de formação universitária, e dentre eles está a constante tensão entre teoria e prática. Este trabalho tem como base as reformulações curriculares de um curso de Química Licenciatura de uma universidade comunitária do Rio Grande do Sul tendo como objetivo explorar as concepções estabelecidas pelos professores formadores, evidenciando desafios e possibilidades à formação docente. A pesquisa foi realizada com os professores envolvidos na reformulação curricular, que responderam a um questionário estruturado. O processo de análise foi realizado por meio da Análise Textual Discursiva. Os resultados são apresentados por figuras que contém as categorias que surgiram relacionando-as com as principais ideias emergentes. Entre esses, destacam-se a importância de desenvolver uma prática reflexiva ao longo da formação docente, ter disciplinas capazes de aliar saberes técnicos aos práticos e a necessidade do professor formador estar envolvido num processo de formação contínua.

Palavras-chave: Educação química. Formação docente. Racionalidade prática.

Abstract: The teacher formation brings up innumerable challenges to be faced in a university formation course, among them is the constant tension between theory and practice. This work is based on the curricular reformulations of a course Chemistry Licenciature of a community university of Rio Grande do Sul aiming to explore the established conceptions by teacher trainers, highlighting the challenges and possibilities on teacher education. The research was carried out with the teachers involved in the curricular reformulation, who answered a structured questionnaire. The process of analysis was conduced of the Discursive Textual Analysis. The results are presented by figures that contain the categories that have emerged relating them to the main emerging ideas. Among these highlight the importance to develop a reflective practice throughout teacher formation, have disciplines capable of allying technical knowledge to practice and the need of the teacher to be involved in a process of continuous formation.

Keywords: Chemical education. Teacher formation. Practical rationality.

Resumen: La formación docente revela inúmeros desafíos a enfrentarse en un curso de formación universitaria, entre ellos está la constante tensión entre teoría y práctica. Este trabajo tiene como base las reformulaciones curriculares de un curso de Química Licenciatura de una universidad comunitaria de Rio Grande do Sul teniendo como objetivo explorar las concepciones establecidas por los profesores formadores, evidenciando desafíos y posibilidades a la formación docente. La investigación fue realizada con los profesores involucrados en la reformulación curricular, que han contestado a un cuestionario estructurado. El proceso de análisis fue realizado por medio del Análisis Textual Discursivo. Los resultados se presentan por figuras que contienen las categorías que han surgido relacionándolas con las principales ideas emergentes. Entre esos, se destacan la importancia de desarrollar una práctica reflexiva a lo largo de la formación docente, tener asignaturas capaces de aliar saberes técnicos a los prácticos y la necesidad de que el profesor formador esté involucrado en un proceso de formación continua.

Palabras clave: Educación química. Formación docente. Racionalidad práctica.

- Recebido em 4 de outubro de 2017 • Aprovado em 27 de maio de 2018 e-ISSN: 2177-5796

DOI: http://dx.doi.org/10.22483/2177-5796.2019v21n1p243-261

Copyright @ 2019. Conteúdo de acesso aberto, distribuído sob os termos da Licença Internaonal da CreativeCommons - CC BY-NC-SA Atribuição Não Comercial (https://br.creativecommons.org/licencas/) - Permite distribuição e reprodução, desde que atribuam os devido créditos à publicação, ao autor(es) e que licenciem as novas criações sob termos idênticos. 


\section{Considerações iniciais}

$\mathrm{Na}$ atualidade, a formação docente impõe muitos desafios a professores formadores, num sentido de possibilitar, cada vez mais, que os acadêmicos possam se inteirar e entender o que a realidade profissional vai lhes proporcionar. Com isso, é necessário que, durante a formação, os estudantes consigam perceber a integração entre os conhecimentos debatidos na universidade e a realidade da escola, seu futuro campo de atuação profissional.

Nesse sentido, o curso de Química Licenciatura de uma universidade comunitária do Rio Grande do Sul procurou adequar, com base em reformulações curriculares estabelecidas nos anos de 2002 (UNIVERSIDADE DE PASSO FUNDO, 2002) e 2008 (UNIVERSIDADE DE PASSO FUNDO, 2008), a formação docente ao contexto exigido pelas legislações propostas pelo MEC (BRASIL, 2001), às exigências institucionais e, também, em acordo com as perspectivas oriundas do debate profissional, a partir de diálogos estabelecidos no Núcleo de Educação Química (NEQ) da instituição, visando à evolução do curso com o intuito de formar um profissional autônomo, crítico e pesquisador de sua práxis (DEL PINO; LAUXEN, 2016).

Com base nos pressupostos político-pedagógicos orientadores do MEC e que foram assumidos para a consolidação da formação de um novo educador químico, muitos desafios e possibilidades surgiram como necessidade para se colocar em prática as concepções acerca da formação pedagógica em Química. Por meio de uma entrevista estruturada realizada com os professores diretamente envolvidos nas reformulações curriculares do curso de Química Licenciatura (comissões das reformulações de 2002 e de 2008), buscou-se entender quais foram as concepções que se configuraram nesse processo, procurando perceber os fatores que foram balizadores para a construção de um novo currículo para a formação docente em Química.

Tendo por base metodológica a Análise Textual Discursiva (MORAES; GALIAZZI, 2013), as respostas das entrevistas foram analisadas como forma de entendimento das propostas estabelecidas, a fim de compor os parâmetros e as possibilidades atribuídos para a formação docente em Química. Com base nisso, este trabalho se fundamenta buscando as contribuições desta pesquisa para o estudo de doutoramento que pretende analisar, criticamente, a reformulação curricular estabelecida num curso de licenciatura em Química de uma universidade comunitária do Rio Grande do Sul, bem como as consequências relacionadas ao processo de ensinoaprendizagem em Química. 
TRES, Lairton; DEL PINO, José Claudio. Concepções acerca da formação docente em química: desafios e possibilidades.

\subsection{0 caminho metodológico}

Para realizar a análise dos resultados desta investigação, optou-se pela metodologia da Análise Textual Discursiva (ATD) que, de acordo com Moraes e Galiazzi (2013), é

[...] uma metodologia de análise de dados e informações de natureza qualitativa com a finalidade de produzir novas compreensões sobre os fenômenos e discursos. Insere-se entre os extremos da análise de conteúdo tradicional e a análise de discurso, representando um movimento interpretativo de caráter hermenêutico (p. 7).

Neste estudo, é fundamental a compreensão da metodologia utilizada e, para isso, é necessário o entendimento das metodologias de análise: Análise de Conteúdo (AC), Análise de Discurso (AD) e Análise Textual Discursiva (ATD). Para facilitar a compreensão, neste caso, uma analogia pode ser estabelecida: como se fosse um exercício de se movimentar num rio onde a AC "assemelha-se ao deslocar-se rio abaixo, a favor da correnteza [...] a AD corresponde a mover-se rio acima, contra o movimento da água. A ATD pode tanto inserir-se num como no outro desses movimentos" (MORAES; GALIAZZI, 2013, p. 142). Com isso, entende-se que a AC procura fazer a descrição dos fatos seguida de interpretação, movendo-se a favor da correnteza e, eventualmente, opondo-se a ela, ou seja descrevendo os fatos de acordo como são, buscando a sua compreensão; já a AD envolve-se com uma interpretação radical, seguindo contra a correnteza, ou seja, busca a interpretação crítica dos fatos, normalmente, opondo-se a eles; e a ATD, embora tenha uma aproximação maior com a AC, busca a reconstrução dos significados, visando a navegar nem a favor, nem contra a correnteza, mas procurando explorar as profundidades do rio, ou seja, dando um sentido mais amplo para a interpretação (MORAES; GALIAZZI, 2013). Desse modo, na ATD "sua interpretação tende principalmente para a construção ou reconstrução teórica, numa visão hermenêutica, de reconstrução de significados a partir das perspectivas de uma diversidade de sujeitos envolvidos nas pesquisas" (MORAES; GALIAZZI, 2013, p. 145).

É por esse motivo que se optou por proceder a análise da entrevista estruturada, por meio da ATD, sendo, para isso, necessária a reconstrução dos argumentos pesquisados, tomando por referência a interpretação dos fatos, tendo como base a dedução e a intuição do pesquisador. Assim, é necessário seguir a sequência estabelecida por Moraes e Galiazzi (2013) como sendo: “a desconstrução dos textos do 'corpus', a unitarização; o estabelecimento de relações entre os 
elementos unitários, a categorização; o captar o emergente em que a nova compreensão é comunicada e validada" (p. 12).

Diante desse desafio, novas perspectivas são estabelecidas para o entendimento das concepções necessárias à formação docente em Química no contexto da instituição em que se realizou a pesquisa. Esses resultados poderão constituir-se em referência para a ampliação do universo de discussão do tema.

\subsection{O caminho percorrido na investigação}

Esta pesquisa surge pela necessidade de identificar, a partir dela, as principais categorias que emergem para justificar o imperativo de reformulação curricular, bem como o propósito envolvido por tais reformulações. Diante disso, a fim de favorecer a compreensão e, posteriormente, confrontar os dados obtidos com os resultados de uma análise documental já realizada paralelamente a este estudo, realizou-se a entrevista estruturada, com questionário composto de questões abertas (GIL, 1999, p. 121), com os professores $^{1}$ que participaram efetivamente na elaboração do novo Projeto Político Pedagógico do curso de Química Licenciatura, em 2002 e, depois, em 2008. O questionário contou com dez questões, conforme é apresentado no Quadro 1, que foram aplicadas para seis professores do curso no ano de 2016.

\footnotetext{
${ }^{1}$ Os professores formadores entrevistados foram designados pela letra "P" seguido por sequência numérica.
} 
TRES, Lairton; DEL PINO, José Claudio. Concepções acerca da formação docente em química: desafios e possibilidades.

Quadro 1 - Questionário relacionado à entrevista estruturada

\section{QUESTÕES DA ENTREVISTA ESTRUTURADA}

1 - O que motivou a realização da reforma curricular no Curso de Química Licenciatura na instituição em $2002 / 2003$ ?

2 - Quais os principais problemas apresentados no antigo currículo (anterior à reforma estabelecida em 2002/2003)?

3 - Como avalia o processo de formação desenvolvido no Curso de Química Licenciatura na instituição a partir da reforma curricular?

4 - O que se espera do profissional egresso do curso no desenvolver do seu trabalho pedagógico na escola?

5 - Quais aspectos considera relevantes para a formação dos novos profissionais que são desenvolvidos no Curso de Química Licenciatura da instituição?

6 - O que representam as disciplinas de cunho pedagógico desenvolvidas no decorrer da formação desde os primeiros níveis do curso?

7 - Como se deu (se dá) o envolvimento dos professores do curso com a nova proposta estabelecida a partir da reformulação curricular?

8 - Quais os principais problemas apresentados, hoje, relacionados ao processo de formação dos professores de Química/Ciências na instituição?

9 - Sobre a reformulação curricular de 2008 , o que tem a considerar?

10 - Outras questões e/ou sugestões que considera relevante:

Fonte: Elaboração própria.

As respostas obtidas a partir das entrevistas realizadas foram analisadas por meio da ATD, iniciando com o processo de estabelecimento das unidades de análise, que são apresentadas no Quadro 2 e que foram elencadas, seguindo a numeração de acordo com a ordem das questões. Toma-se como exemplo a questão 2, onde os itens 2.1, 2.2, 2.3 e 2.4, se relacionam, cada um, a um dos diferentes itens unitarizados para a mesma questão 2. 
TRES, Lairton; DEL PINO, José Claudio. Concepções acerca da formação docente em química: desafios e possibilidades.

Quadro 2 - Unidades de análise com base nas respostas das entrevistas estruturadas realizadas

\section{UNIDADES DE ANÁLISE}

1.1 Exigência do MEC em desvincular os cursos de licenciatura dos cursos de bacharelado

1.2 Necessidade de inserir a prática curricular ao longo do curso

2.1 O currículo não atendia à formação do professor como alguém que vai se constituindo ao longo da graduação

2.2 Forte tendência para a formação técnica com poucas disciplinas pedagógicas

2.3 Disciplinas pedagógicas e preparação para o estágio somente no final do curso

2.4 Modelo para o processo de ensino-aprendizagem baseado na reprodução de conceitos

3.1 Mudança significativa na formação do perfil do professor

3.2 O educar pela pesquisa passa a ser um dos motes balizadores do processo

3.3 Inserção do acadêmico no contexto da escola desde o início do curso, constituindo-se educador, e fazendo-se pesquisador de uma prática refletiva

3.4 O Núcleo de Educação Química (NEQ) fornece elementos de reflexão aos professores das disciplinas pedagógicas do curso e àquelas de carácter técnico

3.5 O professor-formador com novos olhares ao seu fazer, sendo de forma tácita ou refletida percebida pelo acadêmico

4.1 O egresso se enxergar como um professor pesquisador de sua prática, capaz de refletir sobre as suas ações, na e sobre elas

4.2 O desenvolvimento da autonomia do egresso para propor o seu programa de trabalho

5.1 Formação pela pesquisa, com a interação no contexto real da escola desde o início

5.2 A iniciação da docência por meio das microaulas, da organização dos planos de estudo e trabalho, planos de aula com apresentação e análise crítica pelos colegas e professor

5.3 A construção das Situações de Estudos, possibilitando o desenvolvimento de abordagens diferenciadas no processo do ensinar e aprender

6.1 Formação para a docência, interligando o saber técnico com o saber pedagógico ao longo do curso por meio de disciplinas didático-pedagógicas/prático-pedagógicas/estágios

6.2 Observações e inserções nas salas de aula e acompanhamento do trabalho do professor experiente

7.1 Reformulação de 2002, participação discreta dos professores formadores, com reformulação parcial, com a inserção de disciplinas de educação química e pouca mudança nas disciplinas do núcleo "duro"

7.2 Reformulação de 2008 (exigência institucional), intensa participação de todos os professores na construção da proposta devido aos debates no NEQ

7.3 Articulação entre teoria e prática em todas as disciplinas com a construção de atividades experimentais pelo coletivo de professores

7.4 Maior envolvimento dos professores formadores na melhoria da proposta do curso

8.1 Baixa procura pelos cursos de licenciatura

8.2 Os professores do curso se perceberem como professores de licenciatura

9.1 A atividade experimental como caráter pedagógico de compreender o fenômeno e não de descoberta do fenômeno

9.2 Inserção de disciplinas de caráter humanista por exigência institucional

Quaestio, Sorocaba, SP, v. 21, n. 1, p. 243-261, jan./abr. 2019. 
TRES, Lairton; DEL PINO, José Claudio. Concepções acerca da formação docente em química: desafios e possibilidades.

9.3 A inserção do estágio em Ciências no ensino fundamental além do estágio em Química no ensino médio

10.1 Bom conceito do curso diante da avaliação do MEC e dos estudantes

10.2 Projetos de extensão permitem aos professores das escolas se manterem em interação com a universidade

Fonte: Elaboração própria.

Os aspectos relacionados às unidades de análise que partem das entrevistas estruturadas corroboram os pressupostos apontados nos documentos analisados, tais como, as resoluções do MEC (BRASIL, 2001) e os Projetos Políticos Pedagógicos do curso (UNIVERSIDADE DE PASSO FUNDO, 2002; 2008) e se mostram importantes para entender as tessituras pelas quais se deu a ação desenvolvida. Por meio das unidades de análise, a ATD seguiu com o estabelecimento de relações entre os elementos unitários, a fim de determinar as categorias que emergiram do processo.

\subsection{Os desafios e as possibilidades acerca das concepções estabelecidas}

A partir do exame das unidades de análise foram elencadas as categorias emergentes da pesquisa, às quais, foram analisadas a fim de verificar os desafios e as possibilidades diante da situação proposta: analisar criticamente a reformulação curricular estabelecida e as consequências relacionadas ao processo de ensino-aprendizagem em Química. "[...] um processo de criação, ordenamento, organização e síntese. Constitui, ao mesmo tempo, processo de construção de compreensão dos fenômenos investigados, aliada à comunicação dessa compreensão por meio de uma estrutura de categorias" (MORAES; GALIAZZI, 2013, p. 78). Diante do cruzamento dos dados, foram elencadas as seguintes categorizações: (a) formação tradicional; (b) formação do educador químico; (c) nova concepção de educador químico; (d) atuação do professor formador; e (e) novo perfil do curso de Química Licenciatura. Tais categorizações são apresentadas em forma de figuras que destacam a relação entre categorias e ideias, que são organizadas aleatoriamente e designadas por letras, que, por sua vez, não indicam a sua ordem de importância.

\subsubsection{Formação tradicional}

A categoria (a) destaca a formação tradicional, ficando clara, neste processo, a necessidade de romper com a forma de como o ensino era desenvolvido. Os problemas 
TRES, Lairton; DEL PINO, José Claudio. Concepções acerca da formação docente em química: desafios e possibilidades.

encontrados no currículo antigo e que também serviram para instigar a Reformulação Curricular de 2002 (Cf. Questão 2 da entrevista) são apontados pelos professores como aqueles já evidenciados em outro momento na análise dos documentos do curso, tais como: uma formação mais voltada à técnica, sendo direcionada mais aos conteúdos específicos do que aos pedagógicos. De acordo com o P2 "Essa realidade determinou o fato de as disciplinas de caráter pedagógico não conseguirem romper com o processo tradicional estabelecido, ficando para o final do curso, desconexas do contexto das demais" ainda destaca como aspecto importante em relação aos estágios como "sendo, ainda, os estágios encarados como um momento 'surpresa' de se deparar com a realidade apenas no final da formação” (P2). Desse modo, o egresso passaria a reproduzir o modelo na sua prática profissional, um modelo centrado na reprodução de conceitos.

A formação inicial oferecida nas universidades precisa ser repensada e redirecionada de forma a contribuir para formar um professor capaz de interferir, criativamente, nas situações complexas da escola. O professor enquanto aluno em sua formação inicial é tratado como um sujeito passivo e receptor de conhecimentos, o que contribui para que futuramente incorpore em sua prática profissional o mesmo que lhe foi oferecido (ECHEVERRÍA; SOARES, 2007, p. 181).

Figura 1 - Formação tradicional

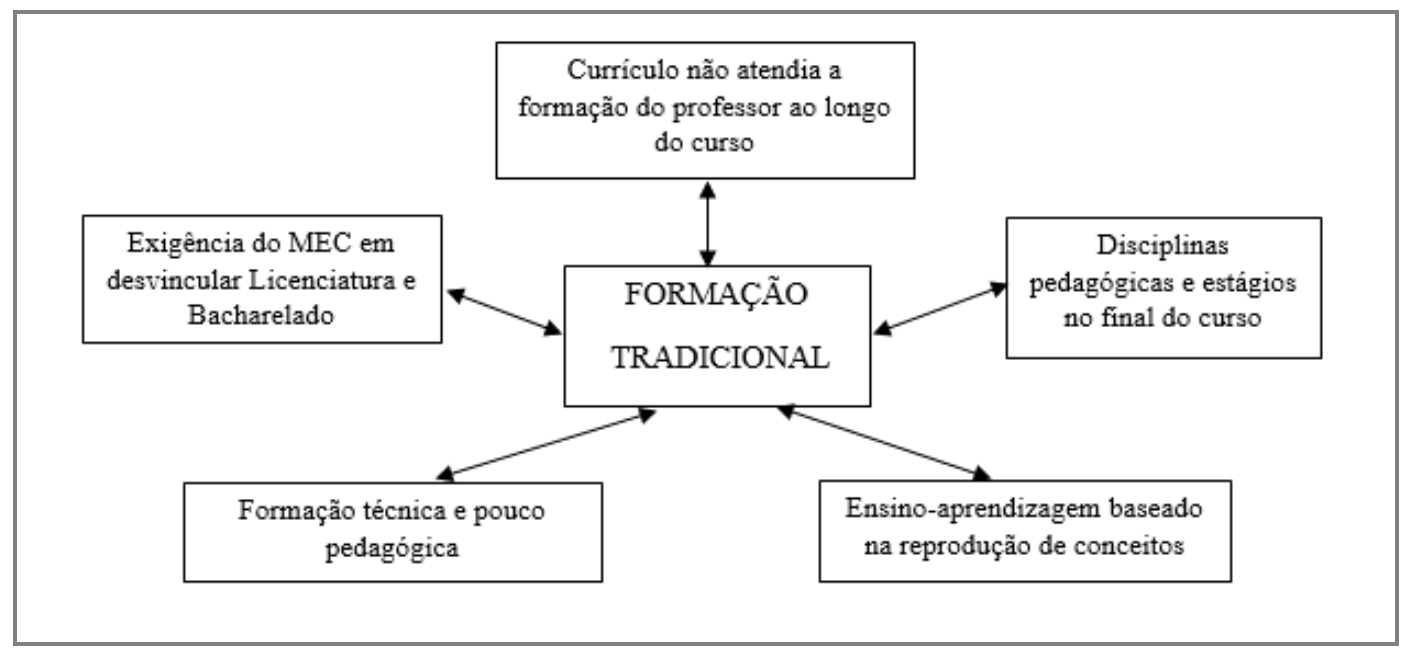

Fonte: Elaboração própria.

Nesse sentido, Freire (2003) destaca que "[...] ensinar não é transferir conhecimento, mas criar as possibilidades para a sua produção ou a sua construção" (p. 22). Assim, a formação tradicional normalmente estabelecida, precisaria abrir espaços para um processo de interação 
entre os sujeitos, pois "não há docência sem discência, as duas se explicam e seus sujeitos apesar das diferenças que os conotam, não se reduzem à condição de objeto um do outro. Quem ensina aprende ao ensinar e quem aprende ensina ao aprender" (FREIRE, 2003, p. 25). Fica claro que, num curso de formação de professores, há a necessidade de um modelo diferente no processo de ensinagem, a fim de que os sujeitos aprendentes, futuros professores, não reproduzam práticas desarticuladas com a realidade no futuro. Há a necessidade de interação entre os sujeitos aprendentes e os seus formadores mediados pelo contexto da vivência da prática, a fim de que "a organização da prática do ensino não mais esteja assentada na transmissão de conhecimentos, mas na interação entre professor/aluno/conhecimento, fazendo da pesquisa uma referência para a formação de estudantes universitários, futuros profissionais” (PIMENTA; ALMEIDA, 2011, p. 40).

\subsubsection{Formação do educador químico}

Pela categoria (b), que destaca a formação do educador químico, percebeu-se, que o educar pela pesquisa e o envolvimento com uma prática refletiva aparece como fundamental para a situação da formação do professor/educador de Química. Tal fato se dá pelo entendimento da realidade, na busca por interação do conhecimento acadêmico com o contexto atual no qual o profissional será inserido. Ensaios desenvolvidos no decorrer do curso com elaboração e análise de microaulas e situações de estudo aparecem como necessários para aprender a fazer a transposição didática do conhecimento científico, aliando-o ao conhecimento pedagógico, assim como emergem também as leituras mediadas e a participação dos docentes no NEQ (Cf. respostas das Questão 3, 5 e 6 da entrevista). 
TRES, Lairton; DEL PINO, José Claudio. Concepções acerca da formação docente em química: desafios e possibilidades.

Figura 2 - Formação do educador químico

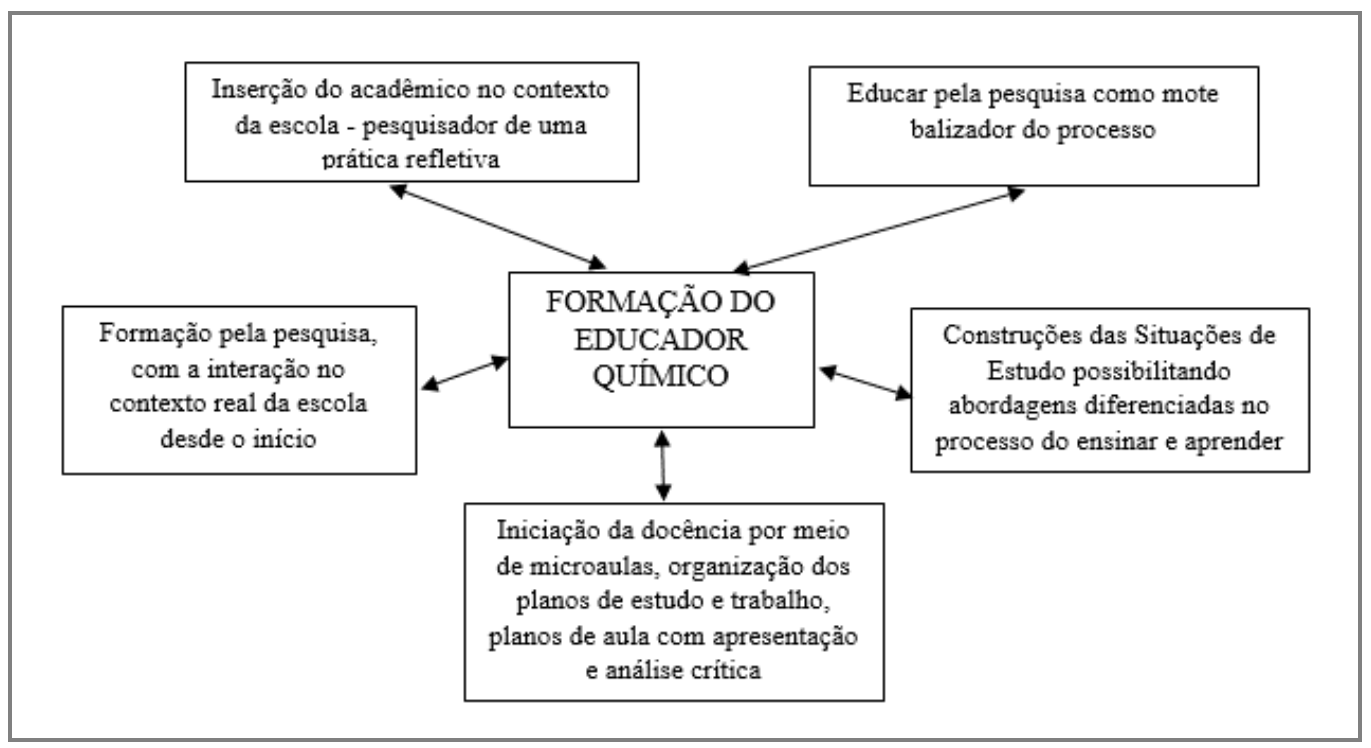

Fonte: Elaboração própria.

Para a formação do educador químico, é importante considerar os princípios apontados para a Educação Química, muitos deles relatados em encontros científicos de professores e em publicações sobre a formação do educador químico. Entre esses, destaca-se a necessidade de uma mudança de paradigma com o abandono do processo de transmissão do conhecimento para a adoção de orientações construtivistas, num processo de construção e reconstrução ativa do conhecimento no processo de ensino-aprendizagem (CHASSOT, 2014). Para romper com o modelo da transmissão do conhecimento, é necessário “desenvolver uma nova metáfora, a do professor/pesquisador em uma prática reflexiva na ação e sobre a ação, superando a dicotomia, própria da racionalidade técnica, que concebe alguns profissionais como produtores de conhecimentos e outros que o aplicam” (MALDANER, 2013, p. 88). Isso fica evidente nas respostas dadas à questão 3 onde os professores destacam que "[...] ao entrar em contato com seu futuro profissional mais cedo, o estudante já pode observar problemas e demandas que pode enfrentar. Assim, se instrumentalizar de forma mais apropriada para resolver os problemas $e$ dar conta das demandas” (P3). Ainda, para P5 a formação desenvolvida no curso é avaliada, “de forma bastante positiva, o que começou a ser refletido nas avaliações externas e ENADE dos licenciandos que passaram a apresentar maiores conhecimentos específicos da sua área de atuação, com um perfil de professor pesquisador e que se reconhece como docente desde o começo do curso de graduação”. Diante disso, percebe-se a importância que tem o processo de 
TRES, Lairton; DEL PINO, José Claudio. Concepções acerca da formação docente em química: desafios e possibilidades.

formação do educador químico na instituição investigada em procurar instigar os acadêmicos a se envolverem, ao longo de sua formação, no contexto da realidade futura em que irão atuar, a escola. "É preciso que os futuros professores participem da pesquisa em todo o processo, que aprendam a tomar decisões, que passem a compreender a ciência como a busca pelo conhecimento nunca acabado, sempre político, que precisa de qualidade formal” (GALIAZZI, 2003, p. 55)

\subsubsection{Nova concepção de educador químico}

Pela categoria (c), que trata da nova concepção de educador químico, espera-se que o egresso "possa se enxergar como um professor pesquisador de sua prática, capaz de refletir as suas ações, na e sobre elas. Que possa fazer isso de forma individual (introspectivamente), mas também, no coletivo dos sujeitos que compõe a escola” (Resposta de P2 para a Questão 4 da entrevista). Esse fator é essencial para o desenvolvimento de sujeitos autônomos e críticos, eternos aprendentes.

Figura 3 - Nova concepção de educador químico

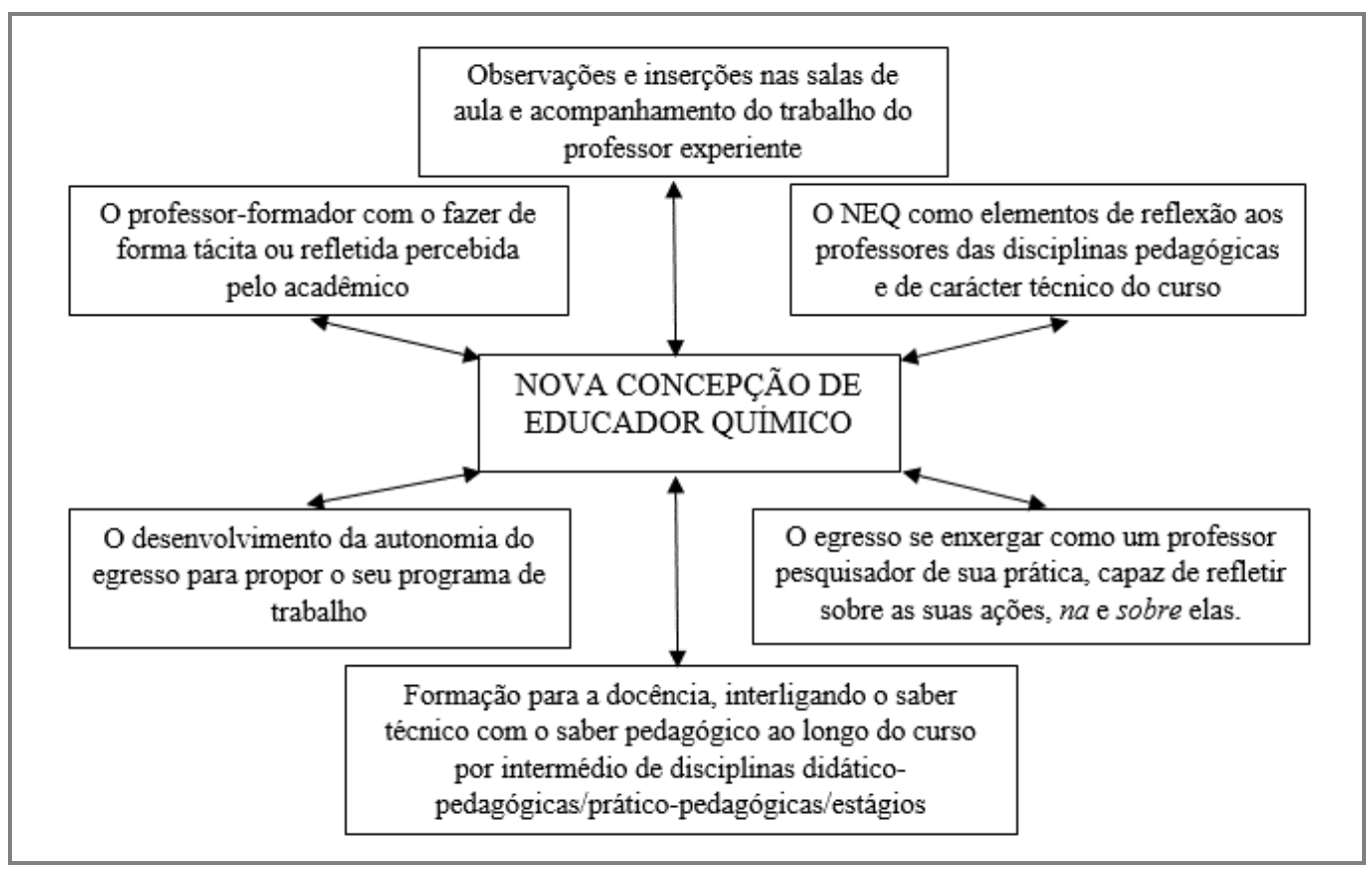

Fonte: Elaboração própria. 
TRES, Lairton; DEL PINO, José Claudio. Concepções acerca da formação docente em química: desafios e possibilidades.

De acordo com Diniz-Pereira e Zeichner (2002), esse fato apoia-se na ideia estabelecida de uma formação de professores, envolvendo a tensão entre um modelo hegemônico e um modelo contra-hegemônico: a racionalidade técnica e a racionalidade prática. Pelo modelo da racionalidade técnica, "o professor é visto como um técnico, um especialista que rigorosamente põe em prática as regras científicas e/ou pedagógicas. Assim, para se preparar o profissional da educação, o conteúdo científico e/ou pedagógico são necessários, o qual servirá de apoio para a sua prática” (DINIZ-PEREIRA; ZEICHNER, 2002, p. 22). Porém, não basta somente o saber técnico, é preciso ir além, num movimento contra-hegemônico estabelecido no ensino tradicional. "Um movimento dos educadores pesquisadores a se estabelecer 'de baixo para cima', como estratégia para a superação dos modelos tradicionais e conservadores da formação docente na qual a pesquisa do que se vivencia na prática passa a ser o mote balizador do processo" (DINIZPEREIRA; ZEICHNER, 2002, p. 40). Com isso, é possível criar um novo modelo capaz de organizar de um modo coletivo, colaborativo e crítico a formação de professores.

Nessa nova concepção de educador químico destaca-se a necessidade de que o processo formativo represente a constituição da "[...] identidade na formação do licenciando, que se reconhece como futuro docente ao longo de toda a formação, que reflete sobre os conhecimentos científicos específicos e relaciona com os saberes pedagógicos” (P5). Para Sacristán e PérezGomes (1998) a prática profissional docente deve ser considerada uma prática intelectual e autônoma e não meramente técnica. Assim, o professor em formação deve ser preparado para se sentir capaz, a partir de um processo de ação e reflexão, de entender que aprende ao ensinar e que ensina porque aprende e que, nesse processo intrínseco, é que vai se constituindo como educador. Para tanto, é fundamental que se perceba como sujeito participante da construção da sua aprendizagem, ativo no processo e não como mero receptor.

\subsubsection{Atuação do professor formador}

Na categoria (d), que trata da atuação do professor formador, percebe-se que a exigência estabelecida pelo MEC passou a ser um compromisso dos professores que compunham a Área de Química, já que, a mudança no contexto da formação se fazia necessária. Ao se indagar sobre como se deu o envolvimento dos professores do curso com a nova proposta, evidencia-se que, em princípio, “os professores participaram de uma forma mais discreta, sendo que a reformulação 
TRES, Lairton; DEL PINO, José Claudio. Concepções acerca da formação docente em química: desafios e possibilidades.

foi parcial, com a inserção de disciplinas de Educação Química e poucas mudanças nas disciplinas de 'núcleo duro,” (Resposta de P2 para a Questão 7 da entrevista). O fato destacado mostra que não houve uma mudança de concepção generalizada no processo de ensinoaprendizagem desenvolvido no curso, em partes porque muitas das disciplinas de caráter técnico são compartilhadas entre os dois cursos: licenciatura e bacharelado. Mas, como destaca P2:

Já na reformulação de 2008, consequência de uma exigência institucional, houve uma intensa participação de todos os professores na construção da proposta. Esta mudança se deu, pois a partir de 2003 passou a existir o Núcleo de Educação Química (NEQ) que consiste num espaço de estudo, debates e discussão do grupo de professores ligados à Área de Química. Em decorrência dos estudos do NEQ, todas as ementas das disciplinas de Química e seus programas foram reformulados, e as mesmas passaram a conter créditos teóricos e práticos, diferentemente do que ocorria anteriormente, onde as disciplinas tinham caráter teórico e outras apenas caráter prático. Essa mudança remete a uma nova lógica de pensar o currículo do curso. (Resposta à Questão 7 da entrevista)

Figura 4 - Atuação do professor formador

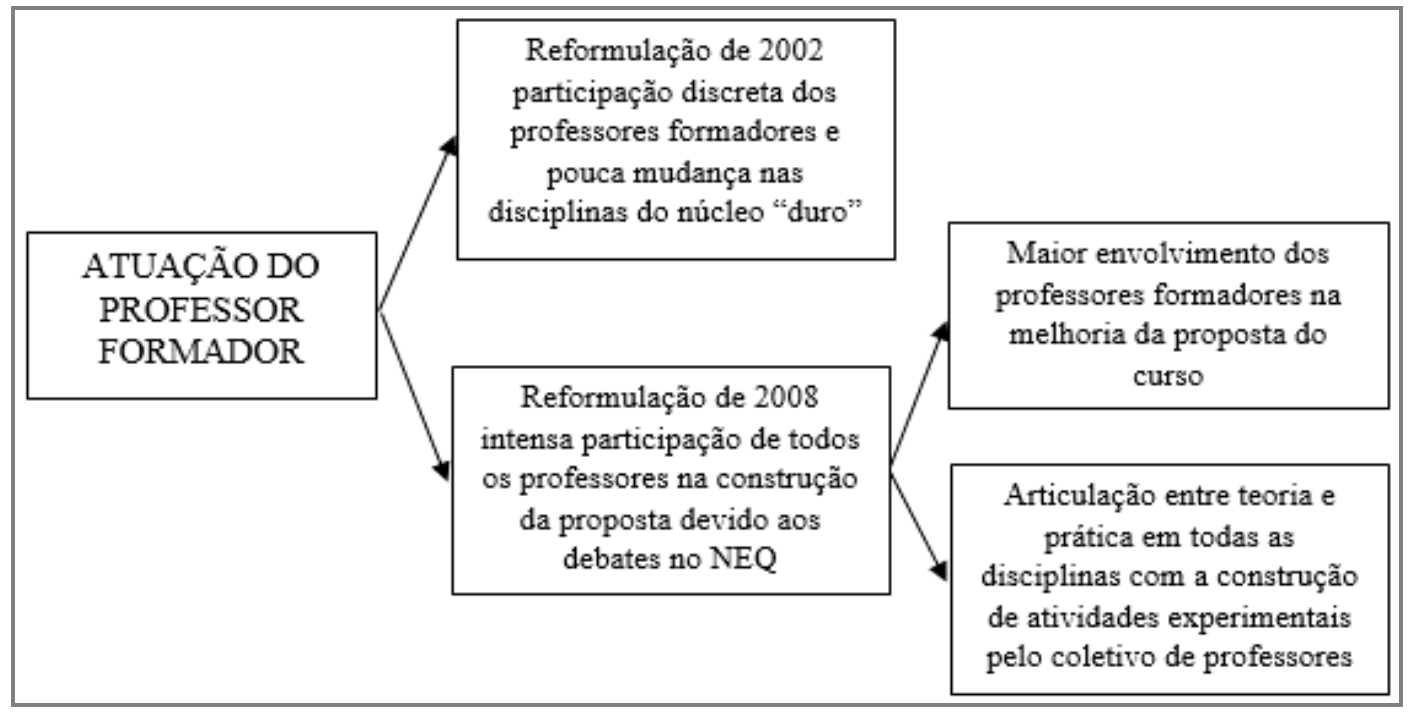

Fonte: Elaboração própria.

Fica claro que os diálogos estabelecidos no processo de reformulação se afinaram com a reivindicação do conjunto de professores acerca da criação de um espaço de discussão e elaboração coletiva imprescindível à licenciatura. Certamente, as discussões para a reformulação curricular de 2002 também tiveram papel decisivo para a criação do NEQ como espaço dialógico e de construção do conhecimento dos docentes do curso. De acordo com Lauxen et al. (2010) o NEQ, Núcleo de Educação Química foi criado em 2003 por iniciativa dos professores que compunham a Área de Química da instituição, tendo como principal objetivo ser um espaço de 
TRES, Lairton; DEL PINO, José Claudio. Concepções acerca da formação docente em química: desafios e possibilidades.

construção coletiva e de busca pela interdisciplinaridade. Um espaço institucionalizado pela universidade, com tempo incluído na carga horária de todos os professores da Área de Química, que permite a troca de experiências e a constante reflexão do fazer pedagógico sendo "um espaço inestimável de formação dos docentes e que se reflete diretamente no ensino de graduação" (LAUXEN et al. 2010, p. 194).

Esse espaço é reconhecido como aspecto importante para a formação continuada dos professores formadores, pois, conforme afirma P6, "a formação para essas mudanças ocorrem através de debates no NEQ, que muito auxilia na organização dos cursos de química da instituição". Por isso, entende-se que a inserção das disciplinas de educação química na Reformulação Curricular de 2002 não conseguiria dar conta sozinha de uma transformação no processo formativo, se os envolvidos com as demais disciplinas não fizessem, também, a sua parte, principalmente na articulação entre teoria e prática, o que se torna efetivo a partir da Reformulação Curricular de 2008. Em relação aos demais docentes do curso, P5 ressalta que esses, “[...] na medida do possível, tem se envolvido no pensar e organizar suas aulas, mesmo que de disciplinas mais específicas dos conhecimentos científicos em química, empregam diferentes metodologias, aulas de laboratório com caráter investigativo, entre outras possibilidades".

Os estudos estabelecidos no NEQ contribuíram para que fosse percebida a importância da articulação entre teoria e prática ao longo da formação acadêmica, num processo contínuo, em que ambas se complementam, não concebendo a prática apenas como comprovação da teoria. Assim, ao professor formador cabe estar voltado à formação do profissional reflexivo, pois, “a instituição universitária não pode se voltar à profissão e aos estágios para garantir a formação de um profissional reflexivo. Isso compete a todos os formadores, com uma intenção firme [...] abandonando a transmissão de saberes acadêmicos plenos" (PERRENOUD, 2002, p. 105), numa abordagem que permita a construção conjunta do conhecimento.

\subsubsection{Novo perfil do curso de química licenciatura}

Pela categoria (e) que trata do novo perfil do curso de Química Licenciatura, é destacado por P2 a notoriedade de que a ação de reestruturação curricular foi motivada, principalmente, pela exigência do MEC em desvincular os cursos de licenciatura dos bacharelados. 
TRES, Lairton; DEL PINO, José Claudio. Concepções acerca da formação docente em química: desafios e possibilidades.

Como em 2002/l já havia sido ofertado, na instituição, o bacharelado separadamente, e em fevereiro o CNE havia expedido as Resoluções CNE $n^{\circ} 1$ e $n^{\circ} 2$ que tratava especificamente a formação de professores para a educação básica, foi entendimento do colegiado do curso em já adequar o novo currículo da licenciatura as respectivas resoluções. [...] Portanto, no semestre de 2002/1 foi realizado as mudanças no currículo para que em julho de 2002 já pudesse haver oferta no vestibular de Química licenciatura com um novo currículo adequado as novas exigência. (Resposta da Questão 1 da entrevista)

O fato de envolver as disciplinas de cunho pedagógico no decorrer da formação, desde os primeiros níveis do curso, é destacado por P2 como possibilidade de que

[...] elas representam a garantia de uma formação para a docência, interligando o saber técnico com o saber pedagógico. $O$ entrelaçamento que vai sendo construído ao longo do curso, nas disciplinas de educação química, fundamentos de ciências, metodologia do ensino, didática, inclusão, fundamentos (legislação), sociologia, ética, psicologia, etc., culminam com os estágios onde ocorre o processo de aplicação no contexto real. Porém, antes desse, o estudante já havia se familiarizado com o contexto da escola, através das observações e inserções nas salas de aula, acompanhando o trabalho do professor experiente. (Resposta da Questão 6 da entrevista)

Somando-se aos esforços e ao empenho estabelecidos no envolvimento de uma formação profissional adequada, os professores destacam um bom conceito na avaliação do MEC por meio do Enade, a satisfação dos estudantes com a sua formação e o envolvimento com professores das escolas em projetos de extensão (Cf. respostas da Questão 10 da entrevista). Também, a importância das atividades experimentais como momento para a compreensão dos fenômenos; o envolvimento em disciplinas de caráter humanista; e o estágio em Ciências, complementando a formação (Cf. respostas da Questão 9 da entrevista).

Apesar disso, alguns problemas são destacados em relação ao processo formativo (Cf. resposta da Questão 08 da entrevista), entre eles: "a baixa procura por cursos de licenciatura" apontada por P2 e também, para P5, que

De maneira geral observa-se uma desmotivação para as licenciaturas, e na Química [...] não é diferente, o que se reflete em procura pequena além de alta evasão, sendo que os que terminam o curso são aqueles que realmente tem interesse na formação. Dificuldade em que todos os professores do curso entendam que são professores de um curso de licenciatura e auxiliem na formação mais específica, didático metodológica, através da modificação de sua própria ação.

Essas preocupações são apontadas como os principais problemas a serem enfrentados no processo de formação de professores de Química/Ciências na instituição. A baixa procura e o desinteresse pelas licenciaturas fazem parte de um contexto da realidade atual em que a profissão professor é desvalorizada sendo necessário, principalmente, para superação desse fato a necessidade de "oferecer-lhes condições de trabalho satisfatórias e remuneração comparável à das outras categorias de emprego que exigem um nível de formação equivalente” (DELORS, 2006, p. 
TRES, Lairton; DEL PINO, José Claudio. Concepções acerca da formação docente em química: desafios e possibilidades.

161). Certamente, esse seria um fator motivador para o interesse dos jovens pelo trabalho docente e auxiliaria na superação da crise educacional vivida na atualidade. Outro aspecto relevante é a necessidade de que todos os professores formadores devem direcionar sua ação para a preparação do professor de química, voltando os conhecimentos específicos a uma dimensão mais aplicada à realidade em que vão atuar.

Figura 5 - Novo perfil do curso de Química Licenciatura

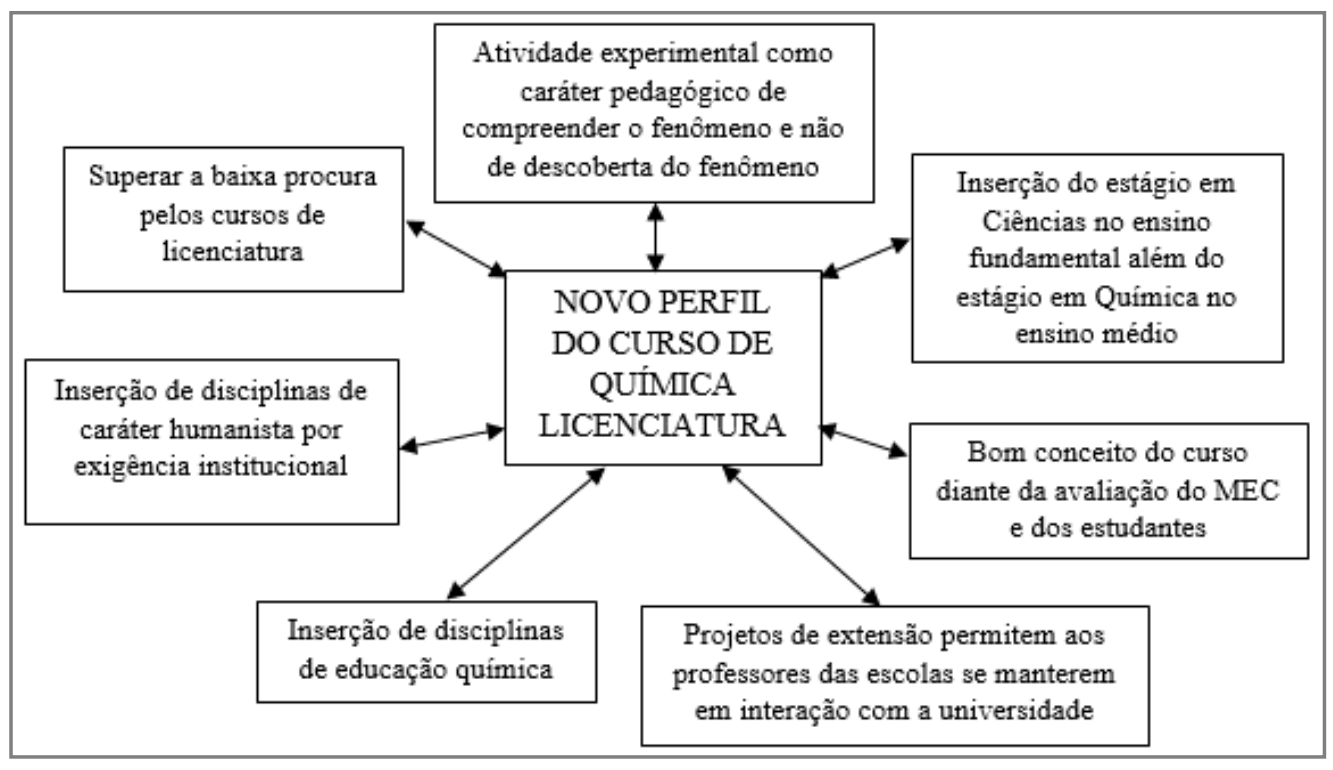

Fonte: Elaboração própria.

No cerne da proposta estabelecida como um novo perfil do curso de Química Licenciatura, está a formação de um profissional reflexivo, a partir da inserção das disciplinas pedagógicas e das de caráter prático pedagógico ao longo da formação docente; está o desenvolvimento das atividades experimentais das disciplinas em geral voltadas à compreensão dos fenômenos e não como confirmação das teorias; e, ainda, a interação com a educação básica. Diante disso, é importante destacar que "a noção de professor reflexivo baseia-se na consciência da capacidade de pensamento e reflexão que caracteriza o ser humano como criativo e não como mero reprodutor de ideias e práticas que lhe são exteriores” (ALARCÃO, 2011, p. 44). 
TRES, Lairton; DEL PINO, José Claudio. Concepções acerca da formação docente em química: desafios e possibilidades.

\section{Considerações}

Pelo processo de Análise Textual Discursiva (MORAES; GALIAZZI, 2013) foi desenvolvido este estudo, a partir da unitarização e da categorização das respostas das entrevistas realizadas com os professores envolvidos nas reformulações curriculares do curso de licenciatura em Química. Com isso, foram percebidos diferentes desafios e possibilidades acerca da formação docente em Química. As categorias evidenciadas apontam para a necessidade de um novo perfil do curso de Química no qual a formação docente precisa estar voltada para uma nova concepção de educador químico, num propósito diferente da formação tradicional normalmente estabelecido, baseado na reprodução e na transmissão do conhecimento. Para romper com esse processo emerge a ideia da formação docente estar voltada para a formação de um educador químico, numa nova concepção, mais abrangente, almejando um profissional reflexivo. Com isso, destaca-se que

[...] a formação de 'profissionais reflexivos' deve se tornar um objetivo explícito e prioritário em um currículo de formação dos professores; em vez de ser apenas uma familiarização com a futura prática, a experiência poderia, desde a formação inicial, assumir a forma simultânea de uma prática 'real' e reflexiva. [...] O que realmente importa é consolidar um percurso de vários anos que permita a construção das competências profissionais essenciais (PERRENOUD, 2002, p. 104).

Para tal situação, desempenha um papel fundamental a atuação do professor formador nas diferentes áreas de atuação, seja nas de conhecimento específico (técnico) ou nas de caráter prático pedagógico. Ambos os profissionais precisam se envolver num processo em conjunto, visando à formação do professor de química como alguém que terá a função de fazer a transposição didática entre o conhecimento científico, típico e essencial da química, para o conhecimento mediado com a realidade, a fim de facilitar a compreensão da leitura do mundo pelos sujeitos aprendentes, também, pelo viés da ciência.

Ao desvincular a licenciatura do bacharelado na reforma curricular na instituição investigada, houve a necessidade de envolvimento dos professores formadores em debates no âmbito da educação química, pois a formação meramente técnica seria insuficiente para uma formação mais qualificada do docente em Química. Junto a isso, o envolvimento do acadêmico com a realidade, na perspectiva da escola, por meio das disciplinas de Educação Química se 
TRES, Lairton; DEL PINO, José Claudio. Concepções acerca da formação docente em química: desafios e possibilidades.

mostrou como um viés necessário para romper com o que era tradicionalmente estabelecido, permitindo a integração entre os saberes teóricos e os saberes da prática (TARDIF, 2014).

A ATD realizada permitiu perceber que o "novo emergente do processo" (MORAES; GALIAZZI, 2013) está na realização de um processo formativo voltado à capacidade do curso de preparar o educador químico de fato, com as características de um profissional reflexivo e pesquisador da sua práxis. Assim, seria o "ensino prático reflexivo como um ambiente para criação de pontes entre a escola e os mundos da universidade e da prática" (SCHÖN, 2000, p. 234). Num sentido mais profundo, o que emerge é a necessidade de o professor formador estar envolvido num processo dialógico constante de ação-reflexão-ação, possibilitado por momentos de diálogos estabelecidos em processo de formação contínua junto ao Núcleo de Educação Química; e a inter-relação ocorrida por meio das disciplinas de educação química que procuram aliar os saberes do conhecimento técnico aos saberes da prática no contexto da formação docente ao longo do curso.

\section{Referências}

ALARCÃO, I. Professores reflexivos em uma escola reflexiva. 8. ed. São Paulo: Cortez, 2011.

BRASIL. Conselho Nacional de Educação. Câmara de Educação Superior. Parecer CNE/CES 1.303/2001. Diretrizes Curriculares Nacionais para os Cursos de Química. Diário Oficial da União, Brasília, 7 dez. 2001. Seção 1. p. 25. (DCNEM)

CHASSOT, A. Para que(m) é útil o ensino? 3. ed. Ijuí: Ed. Unijuí, 2014.

DEL PINO, J. C.; LAUXEN, A. A. O professor-formador e a sua constituição na dimensão reflexiva: existência de espaços/tempos de formação em serviço. Atos de Pesquisa em Educação, Blumenau, v. 11, n. 3, p. 737-754, set./dez. 2016.

DELORS, J. Educação: um tesouro a descobrir - Relatório para a UNESCO da Comissão Internacional sobre Educação para o século XXI. 10. ed. São Paulo: Cortez; Brasília: MEC/UNESCO, 2006.

DINIZ-PEREIRA, J. E.; ZEICHNER, K. M. (org.). A pesquisa na formação e no trabalho docente. Belo Horizonte: Autêntica, 2002.

ECHEVERRÍA, A. R.; SOARES, M. H. F. B. Um núcleo de pesquisa em ensino de ciências (NUPEC) e a mudança nos parâmetros da formação inicial e continuada de professores. In: ZANON, L. B.; MALDANER, O. A. (org.) Fundamentos e propostas de ensino de química para a educação básica no Brasil. Ijuí: Ed. Unijuí, 2007. p. 171-189. 
FREIRE, P. Pedagogia da autonomia: saberes necessários à prática educativa. 28 ed. São Paulo: Paz e Terra, 2003.

GALIAZZI, Maria C. Educar pela pesquisa: ambiente de formação de professores de ciências. Ijuí: Ed. Unijuí, 2003.

GIL, A. C. Métodos e técnicas de pesquisa social. 5. ed. São Paulo: Atlas, 1999.

LAUXEN, A. et al. A formação inicial em química no contexto de uma universidade comunitária. In: ECHEVERRÍA, A. R.; ZANON, L. B. (org.) Formação superior em química no Brasil: práticas e fundamentos curriculares. Ijuí: Ed. Unijuí, 2010. p. 179-199. (Coleção educação em química).

MALDANER, O. A. A formação inicial e continuada de professores de química: professor/pesquisador. 4. ed. Ijuí: Ed. Unijuí, 2013.

MORAES, R.; GALIAZZI, M. C. Análise textual discursiva. 2. ed. rev. Ijuí: Ed. Unijuí, 2013.

PERRENOUD, P. A prática reflexiva no ofício de professor: profissionalização e razão pedagógica. Porto Alegre: Artmed, 2002.

PIMENTA, S. G.; ALMEIDA, M. I. (org.). Pedagogia universitária: caminhos para a formação de professores. São Paulo: Cortez, 2011.

SACRISTÁN, J. G.; PÉREZ-GÓMEZ, A. I. Compreender e transformar o ensino. 4. ed. Porto Alegre: ArtMed, 1998.

SCHÖN, D. Educando o profissional reflexivo: um novo design para o ensino e a aprendizagem. Porto Alegre: Artmed, 2000.

TARDIF, M. Saberes docentes e formação profissional. 17. ed. Petrópolis: Vozes, 2014.

UNIVERSIDADE DE PASSO FUNDO. Projeto pedagógico do curso de química. Passo Fundo: UPF, 2002.

UNIVERSIDADE DE PASSO FUNDO. Projeto pedagógico de curso (PPC) - Atualização Química LP. Passo Fundo: UPF, 2008. 